\title{
MENGAJAR MENGAJI DI TPA NURUL IMAN
}

\section{NAMA : NUR AZIZAH AINUN RAZAK \\ NIM: 9173770410043}

Email: andiainun606@gmail.com

1.Bentuk Kegiatan

Mengajar mengaji Di TPA Nurul Iman.

\section{Lokasi}

Dusun bontoa

3.Hari/Tanggal

Waktu

Kamis, 08 Oktober 2020

Jam 15:00 s/d 15:59

\section{Peserta yang Dilibatkan}

- Santri dan santriwati

- Ustazah

- Mahasiswa

5.Alasan Diadakannya

Untuk memudahkan anak-anak pengenalan dalam dan memahami serta memca dengan baik dan benar dan mengajarkannya kembali kepada yang belum tahu, serta kegiatan ini harus dilakukan secara rutin.

\section{Tujuan dan Manfaat}

Tujuan dari mengajar mengaji khususnya pada umur 5-12 tahun. Kegiatan mengajar ini dilaksanakan untuk anak-anak TPA Nurul Iman gampong suka ramai

Mamfaatnya: guna menciptakan generasi yang islami bisa membaca kitab suci Al-QURAN,

memahami isi kandungannya seta membiasakan untuk menjalankannya. 


\section{Produk Kegiatan (Jika}

Ada)

\section{Deskripsi Kegiatan}

Mengajar mengaji di TPA adalah kegiatan yang dilakukan secara bersamasama dalam mengajarkan AL-QURAN kepada anakanak di bontoa serta ingin adapun tujuan dari kegiatan mengajar di TPA ini adalah anak-anak dapat memahami dan membaca AL-QURAN dengan baik dan benar. Sasaran yang ingin dicapai adalah anak-anak semakin rajin dan lancar membaca AL-QURAN. 


\section{Referensi Wajib}

- HERIANTO, H., \& Amir, A. S. (2020, September 10). Pedoman Pelaksanaan Kuliah Kerja Lapangan Plus (KKLP) Mahasiswa STIE dan STKIP YAPTI Jeneponto. https://doi.org/10.31219/osf.io/7dvpk

\section{Referensi Tambahan (Jika Ada)}

